
February 1946

\title{
PURIFICATION AND PROPERTIES OF 29 PARAFFIN, 4 ALKYLCYCLOPENTANE, 10 ALKYLCYCLOHEXANE, AND 8 ALKYLBENZENE HYDROCARBONS ${ }^{1}$
}

By Alphonse F. Forziati, ${ }^{2}$ Augustus R. Glasgow, Jr., Charles B. Willingham, and Frederick D. Rossini

\section{ABSTRACT}

This report gives the results of the purification and measurements of refractive index $\left(n_{D}\right.$ at $20^{\circ}$ and $25^{\circ} \mathrm{C}$ ), density (at $20^{\circ}$ and $25^{\circ} \mathrm{C}$ ), boiling point and pressure coefficient of the boiling point (at $1 \mathrm{~atm}$ ) and, except for four of the compounds, the freezing point, together with the calculated amount of impurity, of samples of 51 hydrocarbons, including 29 paraffins, 4 alkylcyclopentanes,

10 alkylcyclohexanes, and 8 alkylbenzenes.

\section{CONTENTS}

II. Materials and purification

III. Refractive indices_...

IV. Densities__._. 135

V. Boiling points

VI. Freezing points and purities

VII. References _........ 136

\section{INTRODUCTION}

In connection with the work of the American Petroleum Institute Research Project 6 at this Bureau on the analysis, purification, and properties of hydrocarbons, samples of 50 hydrocarbons, including 29 paraffins, 3 alkylcyclopentanes, 10 alkylcyclohexanes, and 8 alkylbenzenes, were purified in the period from March 1941 to May 1943. On these 50 compounds, plus an additional one (cyclopentane) not requiring further purification, measurements were made of the boiling point, freezing point, refractive index, and density. This paper gives the results of the purification and measurements of these properties.

\section{MATERIALS AND PURIFICATION}

In table 1 are given the sources of the materials from which (except for the cyclopentane supplied by M. R. Fenske, which was not further purified) the final "best" samples of the compounds were obtained by

1 This investigation was performed at the National Bureau of Standards as part of the work of the American Petroleum Institute Research Project 6 on the Analysis, Purification, and Properties of Hydrocarbons.

${ }_{3}$ Research Associate on the American Petroleum Institute Research Project 6 at the National Bureau of Standards. 
purification in the distillation laboratory of the API Research Project 6. As indicated by table 1, the starting materials were supplied from eight different laboratories, as follows: 24 from the API Hydrocarbon Research Project (now the API Research Project 45) at the Ohio State University, Columbus, Ohio; 15 from the API Research Project 6 at the National Bureau of Standards; 2 from the Petroleum Refining Laboratory at the Pennsylvania State College; 2 from the Ethyl Corporation, Detroit, Mich.; 2 from the Barrett Division of the Allied Chemical Corporation, New York, N. Y.; 2 from the Dow Chemical Co., Midland, Mich.; 1 from the Humble Oil \& Refining Co., Houston, Tex.; and 3 as commercially available materials from the Phillips Petroleum Co., Bartlesville, Okla.

TABLE 1.-Information on the sources of the starting materials and on the purification

\begin{tabular}{|c|c|c|c|c|}
\hline \multirow{2}{*}{ Compound } & \multirow{2}{*}{$\begin{array}{l}\text { Source of } \\
\text { starting } \\
\text { material a }\end{array}$} & \multicolumn{3}{|c|}{ Purification b } \\
\hline & & Kind & $\begin{array}{l}\text { Still } \\
\text { No. }\end{array}$ & $\begin{array}{l}\text { Time of } \\
\text { distillation }\end{array}$ \\
\hline $\begin{array}{l}\text { PARAFFINS } \\
\text {-Pentane } \\
\text { 2-Methylbutane (isopentane) } \\
n \text {-Hexane } \\
\text { 2-Methylpentane } \\
\text { 3-Methylpentane }\end{array}$ & \begin{tabular}{l} 
Phillips... \\
\hdashline do do \\
PIR 6. \\
\hdashline do \\
\end{tabular} & $\begin{array}{l}\text { A zeotropic (methanol) } \\
\text { Regular } \\
\text { Azeotropic (methanol) } \\
\text { do }\end{array}$ & $\begin{array}{l}\mathrm{D} \\
\mathrm{D} \\
\mathrm{H} \\
\mathrm{H} \\
\mathrm{H}\end{array}$ & $\begin{array}{l}12 / 2 / 42 \text { to } 12 / 13 / 42 \\
3 / 30 / 43 \text { to } 4 / 17 / 43 \\
2 / 14 / 42 \text { to } 2 / 26 / 42 \\
5 / 6 / 42 \text { to } 5 / 14 / 42 \\
5 / 14 / 42 \text { to } 5 / 22 / 42\end{array}$ \\
\hline $\begin{array}{l}\text { 2,2-Dimethylbutane } \\
\text { 2,3-Dimethylbutane } \\
\text { n-Heptane } \\
\text { 2,2-Dimethylpentane } \\
\text { 3,3-Dimethylpentane........... }\end{array}$ & $\begin{array}{l}\text { Phillips.-. } \\
\text { Penn State } \\
\text { APIRP 6. } \\
\text { Ethyl. } \\
-\end{array}$ & 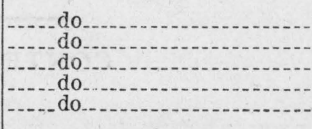 & $\begin{array}{l}J \\
J \\
F \\
I \\
I\end{array}$ & $\begin{array}{l}1 / 1 / 43 \text { to } 1 / 8 / 43 \\
7 / 7 / 42 \text { to } 7 / 16 / 42 \\
12 / 29 / 42 \text { to } 1 / 8 / 43 \\
4 / 14 / 41 \text { to } 4 / 26 / 41 \\
3 / 31 / 41 \text { to } 4 / 11 / 41\end{array}$ \\
\hline $\begin{array}{l}\text { n-Octane } \\
\text { 2-Methylheptane } \\
\text { 3-Methylheptane } \\
\text { 4-Methylheptane } \\
\text { 3-Ethylhexane }\end{array}$ & \begin{tabular}{|c|} 
APIHRP \\
\hdashline do \\
\hdashline do \\
\hdashline do \\
\hdashline do
\end{tabular} & \begin{tabular}{|c} 
Azeotropic (ethanol) \\
- do \\
do do \\
- do
\end{tabular} & $\begin{array}{l}\text { I } \\
\text { I } \\
\text { I } \\
\text { I } \\
\text { I }\end{array}$ & $\begin{array}{l}10 / 10 / 42 \text { to } 10 / 17 / 42 \\
7 / 28 / 42 \text { to } 8 / 9 / 42 \\
8 / 10 / 42 \text { to } 8 / 22 / 42 \\
8 / 24 / 42 \text { to } 9 / 5 / 42 \\
7 / 6 / 42 \text { to } 7 / 17 / 42\end{array}$ \\
\hline $\begin{array}{l}\text { 2,2-Dimethylhexane } \\
\text { 2,-.-Dimethylhexane... } \\
\text { 2,4-Dimethylhexane.-. } \\
\text { 2,5-Dimethylhexane.-. } \\
\text { 3,3-Dimethylhexane... }\end{array}$ & 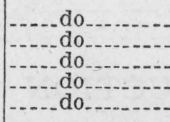 & 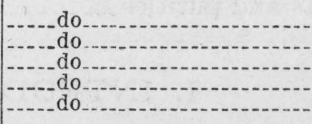 & $\begin{array}{l}\text { I } \\
\text { I } \\
\text { J } \\
\text { I } \\
\text { I }\end{array}$ & $\begin{array}{l}8 / 6 / 41 \text { to } 8 / 23 / 41 \\
4 / 28 / 41 \text { to } 5 / 9 / 41 \\
6 / 6 / 42 \text { to } 6 / 18 / 42 \\
6 / 2 / 42 \text { to } 6 / 13 / 42 \\
7 / 25 / 41 \text { to } 8 / 6 / 41\end{array}$ \\
\hline $\begin{array}{l}\text { 3,4-Dimethylhexane } \\
\text { 2-Methyl-3-ethylpen } \\
\text { 3-Methyl-3-ethylpent } \\
\text { 2,2,3-Trimethylpenta }\end{array}$ & 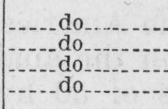 & $\begin{array}{c}\text { do } \\
\text { do do } \\
\begin{array}{c}\text { Azeotropic (methyl Cello- } \\
\text { solve) }\end{array}\end{array}$ & $\begin{array}{l}\text { J } \\
\text { I } \\
\text { I } \\
\text { J }\end{array}$ & $\begin{array}{l}6 / 25 / 42 \text { to } 7 / 6 / 42 \\
11 / 4 / 41 \text { to } 11 / 26 / 41 \\
10 / 16 / 41 \text { to } 11 / 3 / 41 \\
4,26 / 43 \text { to } 5 / 6 / 43\end{array}$ \\
\hline 2,2,4-Trimethylpentane & APIRP & A zeotropic (ethanol) & $\mathrm{D}$ & $12 / 14 / 42$ to $12 / 26 / 42$ \\
\hline $\begin{array}{l}\text { 2,3,3-Trimethylpen } \\
\text { 2,3,4-Trimethylpen }\end{array}$ & APIHRP & - do & I & $\begin{array}{l}7 / 10 / 41 \text { to } 7 / 24 / 41 \\
7 / 17 / 42 \text { to } 7 / 28 / 42\end{array}$ \\
\hline $\begin{array}{l}n \text {-Nonane } \\
n \text {-Decane-2. }\end{array}$ & APIRP 6 & $\begin{array}{l}\text { Azeotropic (Cellosolv) } \\
\text { Azeotropic (butyl Cello- } \\
\text { solve). }\end{array}$ & $\stackrel{\mathrm{E}}{\mathrm{E}}$ & $\begin{array}{l}12 / 29 / 42 \text { to } 1 / 8 / 43 \\
1 / 28 / 43 \text { to } 2 / 3 / 43\end{array}$ \\
\hline ALKYLCYCLOPENTA & & & & \\
\hline Cycloper & Penn Stat & & & \\
\hline$n$-Propylcyclopent & $\begin{array}{l}\text { APIRP 6- } \\
\text { APIHRP. }\end{array}$ & $\begin{array}{l}\text { Azeotropic (methanol) } \\
\text { Azeotropic (methyl Cello- } \\
\text { solve). }\end{array}$ & $\mathrm{D}$ & $\begin{array}{l}4 / 8 / 42 \text { to } 4 / 22 / 42 \\
3 / 26 / 43 \text { to } 4 / 9 / 43\end{array}$ \\
\hline Isopropylcyclor & de & & $\mathrm{J}$ & $3 / 17 / 43$ to $3 / 25 / 43$ \\
\hline ALKYLCYCLOHEXANES & & & & \\
\hline $\begin{array}{l}\text { Cyclohexane } \\
\text { Methylcyclohexane } \\
\text { Ethylcyclohexane }\end{array}$ & \begin{tabular}{l} 
Barrett \\
\hdashline do \\
APIRP $6 .$.
\end{tabular} & $\begin{array}{l}\text { Regular } \\
\text { Azeotropic (methanol) } \\
\text { Azeotropic (methyl Cello- }\end{array}$ & $\begin{array}{l}\mathrm{D} \\
\mathrm{F} \\
\mathrm{I}\end{array}$ & $\begin{array}{l}3 / 8 / 43 \text { to } 3 / 28 / 43 \\
12 / 18 / 42 \text { to } 12 / 28 / 42 \\
11 / 10 / 42 \text { to } 11 / 16 / 42\end{array}$ \\
\hline $\begin{array}{l}\text { cis-1,2-Dimethylcyclohexane } \\
\text { trans-1,2-Dimethylcyclohexane. }\end{array}$ & \begin{tabular}{|l} 
APIHR \\
$-\ldots$ do
\end{tabular} & $\begin{array}{l}\text { Azeotropic (isopropanol) } \\
\text { do... }\end{array}$ & J & $\begin{array}{l}3 / 3 / 42 \text { to } 3 / 19 / 42 \\
2 / 23 / 42 \text { to } 3 / 3 / 42\end{array}$ \\
\hline
\end{tabular}

See footnotes at end of table. 
TABLE 1.-Information on the sources" of the starting materials and on the purification-Continued

\begin{tabular}{|c|c|c|c|c|}
\hline \multirow{2}{*}{ Compound } & \multirow{2}{*}{$\begin{array}{l}\text { Source of } \\
\text { starting } \\
\text { material a }\end{array}$} & \multicolumn{3}{|c|}{ Purification $b$} \\
\hline & & Kind & $\begin{array}{l}\text { Still } \\
\text { No. }\end{array}$ & $\begin{array}{c}\text { Time of } \\
\text { distillation }\end{array}$ \\
\hline \multicolumn{5}{|l|}{ ALKYLCYCLOHEXANES-CON. } \\
\hline cis-1,3-Dimethylcyclohexane..... & APIHRP. & Azeotropic (ethanol) & I & $11 / 26 / 41$ to $12 / 8 / 41$ \\
\hline trans-1,3-Dimethylcy clohexane.. & - & . & I & $1 / 24 / 42$ to $2 / 2 / 42$ \\
\hline cis-1,4-Dimethylcyclohexane & 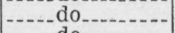 & Azeotropic (isopropanol) & I & $3 / 17 / 42$ to $3 / 27 / 42$ \\
\hline trans-1,4-Dimethylcyclohexane.. & -....do do & Azeotropic (methyl Cello- & $\mathbf{J}$ & $4 / 29 / 42$ to $5 / 12 / 42$ \\
\hline$n$-Propylcyclohexane. & APIRP 6. & Azeotropic (butyl Cello- & J & $3 / 8 / 43$ to $3 / 15 / 43$ \\
\hline ALKYLBENZENES & & & & \\
\hline Benzene & .....do & Regular... & $\mathrm{E}$ & $2 / 4 / 43$ to $2 / 18 / 43$ \\
\hline & Humble. & ..... do & $\mathrm{D}$ & $1 / 26 / 43$ to $2 / 12 / 43$ \\
\hline Ethylbe & APIRP 6. & do & $\mathrm{N}$ & $4 / 29 / 43$ to $5 / 10 / 43$ \\
\hline 0 -Xylene & ..... do & Azeotropic (Cellosolve) & $\mathrm{J}$ & $12 / 14 / 42$ to $12 / 25 / 42$ \\
\hline$m$-Xylene.... & .....do & -... do & 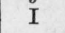 & $12 / 14 / 42$ to $12 / 24 / 42$ \\
\hline$p$-Xylene & .....do do & do do _ & $I$ & $12 / 28 / 42$ to $1 / 15 / 43$ \\
\hline$n$-Propylben & Dow .. & $\begin{array}{l}\text { Azeotropic (butyl Cello- } \\
\text { solve). }\end{array}$ & H & $12 / 18 / 42$ to $12 / 26 / 42$ \\
\hline Isopropylbenzene. . & ..... do & Azeotropic (Cellosolve) & D & $12 / 26 / 42$ to $1 / 14 / 43$ \\
\hline
\end{tabular}

- The abbreviations represent the following laboratories: APIHRP, American Petroleum Institute Hydrocarbon Research Project (now the American Petroleum Institute Research Project 45) at the Ohio State University, Columbus, Ohio. APIRP6, American Petroleum Institute Research Project 6 at the National Bureau of Standards, Washington, D. C. Penn State, Petroleum Refining Laboratory at the Pennsylvania State College, State College, Pa. Ethyl, Chemical Laboratory of the Ethyl Corporation, Detroit, Mich. Barrett, Barrett Division of the Allied Chemical \& Dye Corporation, New York, N. Y'. Dow, Dow Chemical Co., Midland, Mich. Humble, Humble Oil \& Refining Co., Houston, Tex. Phillips, Phillips Petroleum Co., Bartlesville, Okla.

b See text for further details. Methyl Cellosolve is ethylene glycol monomethyl ether; Cellosolve is ethylene gly col monoethyl ether; butyl Cellosolve is ethylene glycol monobutyl ether.

Table 1 lists the kind of distillation used in the purification and the azeotrope-forming substance (if used), together with (for purposes of record) the number of the distilling column and the time during which the distillation was performed. The details of the assembly, testing, and operation of these distilling columns are given in another report [1].* Column D had a Pyrex glass rectifying section consisting of 138 bubble cap sections, each $25 \mathrm{~mm}$ in diameter and $20 \mathrm{~mm}$ in length [7], and the over-all separating efficiency was near 100 theoretical plates at total reflux. The other columns listed in table 1 had rectifying sections packed with stainless-steel helices $13 / 32$ in. in diameter, No. $30 \mathrm{AWG}$ wire) and had the following sizes of rectifying section, capacity of still pot, and approximate number of theoretical plates at total reflux: E, 25 by $2,750 \mathrm{~mm}, 3$ liters, $100 ; \mathrm{F}, 25$ by $2,750 \mathrm{~mm}, 3$ liters, $100 ; \mathrm{H}$, 15 by $2,700 \mathrm{~mm}, 3$ liters, $110 ; \mathrm{I}, 10$ by $2,800 \mathrm{~mm}, 0.75$ liter, $125 ; J, 10$ by $2,800 \mathrm{~mm}, 0.75$ liter, $125 ; \mathrm{N}, 25$ by $2,730 \mathrm{~mm}$, 3 liters, 100 . The distillations were performed at a reflux ratio approximately equal to the number of theoretical plates. The volumes of hydrocarbon charged for azeotropic distillation ranged from $250 \mathrm{ml}$ for the compounds distilled in columns $I$ and $J$ to near $1,500 \mathrm{ml}$ for the compounds distilled in the larger columns.

For this group of compounds, no time was available for the detailed examination of the purity, by measurement of freezing points, ${ }^{3}$ of the

\footnotetext{
* Figures in brackets indicate the literature references at the end of this paper.

3 In more recent work in this laboratory on the preparation of API-NBS hydrocarbons and of NBS Standard Samples in the cooperative program of the American Petroleum Institute and the National Bureau of Standards, the blending of fractions of distillate is done on the basis of measurements of freezing points of appropriate fractions of distillate [2].
} 
distillate as a function of its volume, and the best sample was taken as an appropriately selected "heart" cut (not necessarily the middle part of the distillate) of 50 to $200 \mathrm{ml}$, comprising not more than 25 percent of the distillate. The heart cut was selected largely on the basis of refractive index and boiling point, although, as will be shown in a later report [2], this is a procedure that frequently results in the discarding of the best material. Only this best sample of each compound was subjected to measurements of properties. In each case the sample was filtered through silica gel to remove water and nonhydrocarbon impurities.

\section{REFRACTIVE INDICES}

The measurements of refractive index were made with a precision refractometer, by reference to three hydrocarbons ${ }^{4} 2,2,4$-trimethylpentane, methylcyclohexane and toluene, for which the values of refractive index were determined on a spectrometer with hollow prism by L. W. Tilton, of the Optical Instruments Section of the National Bureau of Standards. The values for the three reference hydrocarbons were reported accurate to \pm 0.00001 . The reference compounds were used as follows: 2,2,4-Trimethylpentane for the paraffin hydrocarbons, methycyclohexane for the naphthene hydrocarbons, and toluene for the aromatic hydrocarbons. By this procedure, the refractometer was actually used only to determine the difference in refractive index, $n_{D}$, between the reference compound and the hydrocarbon being measured. The uncertainties of the values of refractive index, which are reported in table 2, are estimated to be as follows: Precision, \pm 0.00002 to \pm 0.00003 ; accuracy, (including the effect of impurities), \pm 0.00005 to \pm 0.00008 .

1 These three hydrocarbons were substantially the same as those which became available on December 1 , 1944 as NBS Standard Samples of hydrocarbons certified with respect to refractive index at $20^{\circ}, 25^{\circ}$, and $30^{\circ}$ $\mathrm{C}$ at each of 7 wavelengths. 
TABLE 2.-Properties of 29 paraffin, 4 alkylcyclopentane, 10 alkylcyclohexane, and 8 alkylbenzene hydrocarbons ${ }^{\text {b }}$

\begin{tabular}{|c|c|c|c|c|c|c|c|c|c|}
\hline \multirow{2}{*}{ Compound } & \multirow{2}{*}{ Formula } & \multirow{2}{*}{$\begin{array}{c}\text { Boiling } \\
\text { point at } \\
760 \mathrm{~mm} \mathrm{Hg}\end{array}$} & \multirow{2}{*}{$\begin{array}{l}\text { Pressure co- } \\
\text { efficient of } \\
\text { the boiling } \\
\text { point at } \\
760 \mathrm{~mm} \\
\text { dt/dP }\end{array}$} & \multicolumn{2}{|c|}{$\begin{array}{c}\text { Refractive index } \\
n_{D} \text {, at }-\end{array}$} & \multicolumn{2}{|c|}{ Density at a- } & \multirow{2}{*}{$\begin{array}{l}\text { Freezing } \\
\text { point of } \\
\text { the actual } \\
\text { sample in } \\
\text { air at } 1 \mathrm{~atm}\end{array}$} & \multirow{2}{*}{$\begin{array}{l}\text { Calculated } \\
\text { amount of } \\
\text { impurity }\end{array}$} \\
\hline & & & & $20^{\circ} \mathrm{C}$ & $25^{\circ} \mathrm{C}$ & $20^{\circ} \mathrm{C}$ & $25^{\circ} \mathrm{C}$ & & \\
\hline 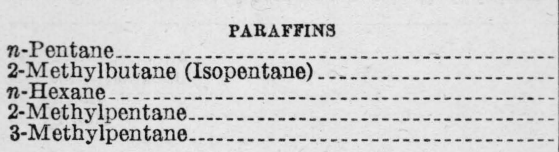 & $\begin{array}{l}\mathrm{C}_{5} \mathrm{H}_{12} \\
\mathrm{C}_{5} \mathrm{H}_{12} \\
\mathrm{C}_{6} \mathrm{H}_{14} \\
\mathrm{C}_{6} \mathrm{H}_{14} \\
\mathrm{C}_{6} \mathrm{H}_{14}\end{array}$ & $\begin{array}{l}\circ C \\
\quad 36.073 \\
27.852 \\
68.740 \\
60.271 \\
63.282\end{array}$ & $\begin{array}{r}\circ C / m m \mathrm{Hg} \\
0.03856 \\
.03815 \\
.04191 \\
.04141 \\
.04182\end{array}$ & $\begin{array}{l}1.35745 \\
1.35369 \\
1.37486 \\
1.37145 \\
1.37652\end{array}$ & $\begin{array}{l}1.35466 \\
1.35084 \\
1.37226 \\
1.36873 \\
1.37386\end{array}$ & $\begin{array}{l}g / m l \\
0.65937 \\
.65315 \\
.66431\end{array}$ & $\begin{array}{l}g / m l \\
0.65481 \\
.65976\end{array}$ & $\begin{array}{l}{ }^{\circ} C \\
-129.751 \\
-160.002 \\
-95.338 \\
-153.700\end{array}$ & $\begin{array}{r}\text { Mole fraction } \\
0.0014 \\
.0054 \\
.0009 \\
.0011\end{array}$ \\
\hline 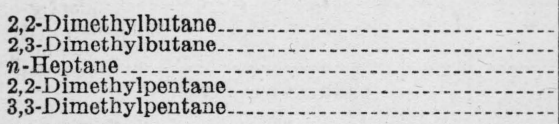 & $\begin{array}{l}\mathrm{C}_{6} \mathrm{H}_{14} \\
\mathrm{C}_{6} \mathrm{H}_{14} \\
\mathrm{C}_{7} \mathrm{H}_{18} \\
\mathrm{C}_{7} \mathrm{H}_{16} \\
\mathrm{C}_{7} \mathrm{H}_{16}\end{array}$ & $\begin{array}{l}49.741 \\
57.988 \\
98.426 \\
79.203 \\
86.069\end{array}$ & $\begin{array}{l}.04117 \\
.04173 \\
.04480 \\
.04394 \\
.04510\end{array}$ & $\begin{array}{l}1.36876 \\
1.37495 \\
1.38764 \\
1.38217 \\
1.39085\end{array}$ & $\begin{array}{l}\text { 1. } 36595 \\
\text { 1. } 37231 \\
\text { 1. } 38517 \\
\text { 1. } 37955 \\
\text { 1. } 38837\end{array}$ & $\begin{array}{l}.64916 \\
.66164 \\
.68367 \\
.67385 \\
.69322\end{array}$ & $\begin{array}{l}.65792 \\
.67949 \\
.66958 \\
.68909\end{array}$ & $\begin{array}{l}-99.991 \\
-128.798 \\
-90.609 \\
-123.794 \\
-134.99(\mathrm{II})\end{array}$ & $\begin{array}{l}.0006 \\
.0010 \\
.0007 \\
.0001 \\
.0017\end{array}$ \\
\hline $\begin{array}{l}n \text {-Octane } \\
\text { 2-Methylheptane } \\
\text { 3-Methylheptane } \\
\text { 4-Methylheptane } \\
\text { 3-Ethylhexane }\end{array}$ & $\begin{array}{l}\mathrm{C}_{8} \mathrm{H}_{18} \\
\mathrm{C}_{8} \mathrm{H}_{18} \\
\mathrm{C}_{8} \mathrm{H}_{18} \\
\mathrm{C}_{8} \mathrm{H}_{18} \\
\mathrm{C}_{8} \mathrm{H}_{18}\end{array}$ & $\begin{array}{l}125.665 \\
117.647 \\
118.925 \\
117.709 \\
118.534\end{array}$ & $\begin{array}{l}.04738 \\
.04691 \\
.04712 \\
.04695 \\
.04719\end{array}$ & $\begin{array}{l}1.39743 \\
1.39494 \\
1.39848 \\
1.39792 \\
1.40162\end{array}$ & $\begin{array}{l}\text { 1. } 39505 \\
\text { 1. } 39257 \\
\text { 1. } 39610 \\
\text { 1. } 39553 \\
\text { 1. } 39919\end{array}$ & $\begin{array}{l}.70252 \\
.69792 \\
.70582 \\
.70463 \\
.71358\end{array}$ & $\begin{array}{l}.69849 \\
.69392 \\
.70175 \\
.70055 \\
.70948\end{array}$ & $\begin{array}{l}-56.806 \\
-109.248 \\
-120.595 \\
-120.983\end{array}$ & $\begin{array}{l}.0004 \\
.010 \\
.006 \\
.0015\end{array}$ \\
\hline 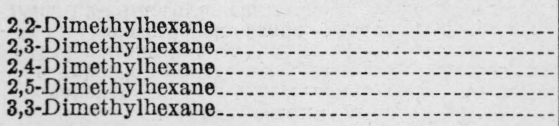 & $\begin{array}{l}\mathrm{C}_{8} \mathrm{H}_{18} \\
\mathrm{C}_{8} \mathrm{H}_{18} \\
\mathrm{C}_{8} \mathrm{H}_{18} \\
\mathrm{C}_{8} \mathrm{H}_{18} \\
\mathrm{C}_{8} \mathrm{H}_{18}\end{array}$ & $\begin{array}{l}106.840 \\
115.607 \\
109.429 \\
109.103 \\
111.969\end{array}$ & $\begin{array}{l}.04650 \\
.04724 \\
.04664 \\
.04646 \\
.04741\end{array}$ & $\begin{array}{l}1.39349 \\
1.40113 \\
1.39534 \\
1.39246 \\
1.40009\end{array}$ & $\begin{array}{l}\text { 1. } 39104 \\
\text { 1. } 39880 \\
\text { 1. } 39291 \\
\text { 1. } 39004 \\
\text { 1. } 39782\end{array}$ & $\begin{array}{r}.69528 \\
.71214 \\
.70036 \\
.69354 \\
.71000\end{array}$ & $\begin{array}{l}.69112 \\
.70809 \\
.69620 \\
.68934 \\
.70596\end{array}$ & \begin{tabular}{c|}
-121.232 \\
-91.405 \\
-126.13
\end{tabular} & $\begin{array}{l}.0018 \\
.010^{-} \\
.0012\end{array}$ \\
\hline 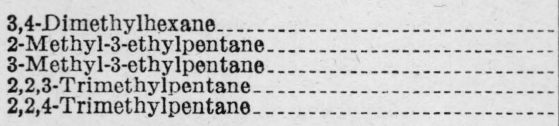 & $\begin{array}{l}\mathrm{C}_{8} \mathrm{H}_{18} \\
\mathrm{C}_{8} \mathrm{H}_{18} \\
\mathrm{C}_{8} \mathrm{H}_{18} \\
\mathrm{C}_{8} \mathrm{H}_{18} \\
\mathrm{C}_{8} \mathrm{H}_{18}\end{array}$ & $\begin{array}{r}117.725 \\
115.650 \\
118.259 \\
109.841 \\
99.238\end{array}$ & $\begin{array}{l}.04752 \\
.07749 \\
.04844 \\
.04755 \\
.04651\end{array}$ & $\begin{array}{l}\text { 1. } 40406 \\
1.40401 \\
1.40775 \\
1.40295 \\
1.39145\end{array}$ & $\begin{array}{l}\text { 1. } 40180 \\
\text { 1. } 40167 \\
1.40549 \\
1.40066 \\
1.38901\end{array}$ & $\begin{array}{l}.71923 \\
.71932 \\
.72742 \\
.71602 \\
.69192\end{array}$ & $\begin{array}{l}.71516 \\
.71522 \\
.72354 \\
.71207 \\
.68777\end{array}$ & $\begin{array}{r}-115.050 \\
-90.996 \\
-112.453 \\
-107.396\end{array}$ & $\begin{array}{l}.005 \\
.005 \\
.007 \\
.0012\end{array}$ \\
\hline $\begin{array}{l}\text { 2,3,3-Trimethylpentane } \\
\begin{array}{l}\text { 2,3,4-Trimethylpentane } \\
n-\text { Nonane-_. } \\
n-\text { Decane }\end{array}\end{array}$ & $\begin{array}{l}\mathrm{C}_{8} \mathrm{H}_{18} \\
\mathrm{C}_{8} \mathrm{H}_{18} \\
\mathrm{C}_{9} \mathrm{H}_{20} \\
\mathrm{C}_{10} \mathrm{H}_{22}\end{array}$ & $\begin{array}{l}114.760 \\
113.467 \\
150.796 \\
174.123\end{array}$ & $\begin{array}{l}.04833 \\
.04761 \\
.04965 \\
.05172\end{array}$ & $\begin{array}{l}1.40750 \\
1.40422 \\
1.40549 \\
1.41189\end{array}$ & $\begin{array}{l}\text { 1. } 40522 \\
\text { 1. } 40198 \\
1.40316 \\
1.40967\end{array}$ & $\begin{array}{l}.72619 \\
.71906 \\
.71766 \\
.73005\end{array}$ & $\begin{array}{l}.72232 \\
.71503 \\
.71382 \\
.72625\end{array}$ & $\begin{array}{r}-101.655 \\
-109.248 \\
-53.606 \\
-29.724\end{array}$ & $\begin{array}{r}.006 \\
.0016 \\
<.003 \\
<.003\end{array}$ \\
\hline
\end{tabular}


TABLE 2.-Properties of 29 paraffin, 4 alkylcyclopentane, 10 alkylcyclohexane, and 8 alkylbenzene hydrocarbons b-Continued

\begin{tabular}{|c|c|c|c|c|c|c|c|c|c|}
\hline \multirow{2}{*}{ Compound } & \multirow{2}{*}{ Formula } & \multirow{2}{*}{$\begin{array}{c}\text { Boiling } \\
\text { point at } \\
760 \mathrm{~mm} \mathrm{Hg}\end{array}$} & \multirow{2}{*}{$\begin{array}{c}\text { Pressure co- } \\
\text { efficient of } \\
\text { the boiling } \\
\text { point at } \\
760 \mathrm{~mm} \\
d t / d P\end{array}$} & \multicolumn{2}{|c|}{$\begin{array}{c}\text { Refractive index a } \\
n_{D} \text { at- }\end{array}$} & \multicolumn{2}{|c|}{ Density at a- } & \multirow{2}{*}{$\begin{array}{l}\text { Freezing } \\
\text { point of } \\
\text { the actual } \\
\text { sample in } \\
\text { air at } 1 \text { atm }\end{array}$} & \multirow{2}{*}{$\begin{array}{l}\text { Calculated } \\
\text { amount of } \\
\text { impurity }\end{array}$} \\
\hline & & & & $20^{\circ} \mathrm{C}$ & $25^{\circ} \mathrm{C}$ & $20^{\circ} \mathrm{C}$ & $25^{\circ} \mathrm{C}$ & & \\
\hline 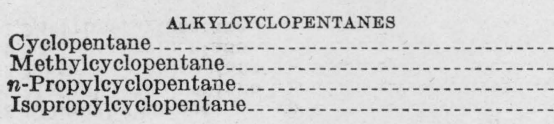 & $\begin{array}{l}\mathrm{C}_{5} \mathrm{H}_{10} \\
\mathrm{C}_{6} \mathrm{H}_{12} \\
\mathrm{C}_{8} \mathrm{H}_{16} \\
\mathrm{C}_{8} \mathrm{H}_{16}\end{array}$ & $\begin{array}{l}\circ C \\
49.262 \\
71.812 \\
130.937 \\
126.415\end{array}$ & $\begin{array}{r}\circ C / m m \mathrm{Hg} \\
0.04003 \\
.04274 \\
.04886 \\
.04913\end{array}$ & $\begin{array}{l}\text { 1. } 40646 \\
\text { 1. } 40969 \\
\text { 1. } 42627 \\
\text { 1. } 42586\end{array}$ & $\begin{array}{l}\text { 1. } 40362 \\
\text { 1. } 40698 \\
\text { 1. } 42393 \\
\text { 1. } 42355\end{array}$ & $\begin{array}{l}g / m l \\
0.74538 \\
.74860 \\
.77625 \\
.77656\end{array}$ & $\begin{array}{l}g / m l \\
0.74045 \\
.74393 \\
.77223 \\
.77257\end{array}$ & $\begin{aligned} & \circ C \\
&-93.917 \\
&-142.468 \\
&-117.402 \\
&-111.462\end{aligned}$ & $\begin{array}{r}\text { Mole fraction } \\
0.0003 \\
.0013 \\
.0032 \\
.0028\end{array}$ \\
\hline 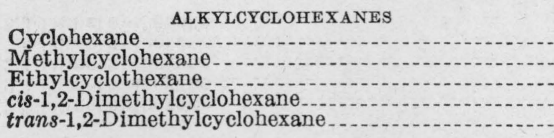 & $\begin{array}{l}\mathrm{C}_{6} \mathrm{H}_{12} \\
\mathrm{C}_{7} \mathrm{H}_{14} \\
\mathrm{C}_{8} \mathrm{H}_{16} \\
\mathrm{C}_{8} \mathrm{H}_{16} \\
\mathrm{C}_{8} \mathrm{H}_{16}\end{array}$ & $\begin{array}{r}80.738 \\
100.934 \\
131.783 \\
129.728 \\
123.419\end{array}$ & $\begin{array}{l}.04376 \\
.04671 \\
.04969 \\
.04988 \\
.04951\end{array}$ & $\begin{array}{l}1.42623 \\
1.42305 \\
1.43304 \\
1.43596 \\
1.42697\end{array}$ & $\begin{array}{l}1.42354 \\
1.42056 \\
1.43073 \\
1.43358 \\
1.42471\end{array}$ & $\begin{array}{r}.77855 \\
.76936 \\
.78792 \\
.79627 \\
.77601\end{array}$ & $\begin{array}{l}.77389 \\
.76501 \\
.78390 \\
.79222 \\
.77204\end{array}$ & $\begin{array}{r}+6.547 \\
-126.597 \\
-111.343 \\
-50.211 \\
-88.284\end{array}$ & $\begin{array}{l}.00003 \\
.0010 \\
.0017 \\
.0008 \\
.004\end{array}$ \\
\hline $\begin{array}{l}\text { cis-1,3-Dimethylcy clohexane } \\
\text { trans-1,3-Dimethylcyclohexane_- } \\
\text { cis-1,4-Dimethylcyclohexane._. } \\
\text { trans-1,4-Dimethylcyclohexane. } \\
n-P r o p y l c y c l o h e x a n e\end{array}$ & $\begin{array}{l}\mathrm{C}_{8} \mathrm{H}_{16} \\
\mathrm{C}_{8} \mathrm{H}_{16} \\
\mathrm{C}_{8} \mathrm{H}_{16} \\
\mathrm{C}_{8} \mathrm{H}_{16} \\
\mathrm{C}_{8} \mathrm{H}_{18}\end{array}$ & $\begin{array}{l}124.450 \\
120.088 \\
124.321 \\
119.351 \\
156.711\end{array}$ & $\begin{array}{l}.04910 \\
.04880 \\
.04921 \\
.04903 \\
.05201\end{array}$ & $\begin{array}{l}1.43085 \\
1.42294 \\
1.42967 \\
1.42090 \\
1.43696\end{array}$ & $\begin{array}{l}\text { 1. } 42843 \\
1.42063 \\
1.42731 \\
1.41853 \\
1.43470\end{array}$ & $\begin{array}{l}.78472 \\
.76603 \\
.78285 \\
.76254 \\
.79349\end{array}$ & $\begin{array}{l}.78055 \\
.76196 \\
.77870 \\
.75835 \\
.78960\end{array}$ & $\begin{array}{l}-93.39 \\
-77.052 \\
-87.730 \\
-37.093 \\
-94.954\end{array}$ & $\begin{array}{r}.023 \\
.015 \\
.010 \\
.004 \\
<.005\end{array}$ \\
\hline 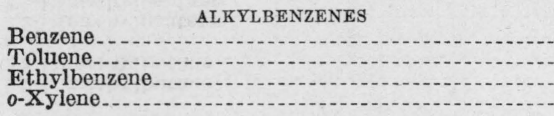 & $\begin{array}{l}\mathrm{C}_{6} \mathrm{H}_{6} \\
\mathrm{C}_{7} \mathrm{H}_{8} \\
\mathrm{C}_{8} \mathrm{H}_{10} \\
\mathrm{C}_{8} \mathrm{H}_{10}\end{array}$ & $\begin{array}{r}80.103 \\
110.623 \\
136.187 \\
-144.414\end{array}$ & $\begin{array}{l}.04273 \\
.04630 \\
.04898 \\
.04969\end{array}$ & $\begin{array}{l}\text { 1. } 50110 \\
\text { 1. } 49682 \\
\text { 1. } 49580 \\
\text { 1. } 50524\end{array}$ & $\begin{array}{l}1.49790 \\
1.49405 \\
1.49319 \\
1.50282\end{array}$ & $\begin{array}{l}.87903 \\
.86683 \\
.86696 \\
.88005\end{array}$ & $\begin{array}{l}.87368 \\
.86220 \\
.86258 \\
.87583\end{array}$ & $\begin{array}{l}+5.506 \\
-95.032 \\
-95.081 \\
-25.225\end{array}$ & $\begin{array}{l}.0004 \\
.0010 \\
.0046 \\
.0010\end{array}$ \\
\hline $\begin{array}{l}m \text {-Xylene } \\
p \text {-Xylene } \\
n \text {-Propylbenzene- } \\
\text { isopropylbenzene-2 }\end{array}$ & $\begin{array}{l}\mathrm{C}_{8} \mathrm{H}_{10} \\
\mathrm{C}_{8} \mathrm{H}_{10} \\
\mathrm{C}_{9} \mathrm{H}_{12} \\
\mathrm{C}_{9} \mathrm{H}_{12}\end{array}$ & $\begin{array}{l}139.102 \\
138.348 \\
159.216 \\
152.393\end{array}$ & $\begin{array}{l}.04903 \\
.04918 \\
.05143 \\
.05076\end{array}$ & $\begin{array}{l}\text { 1. } 49715 \\
\text { 1. } 49580 \\
\text { 1. } 49195 \\
\text { 1. } 49125\end{array}$ & $\begin{array}{l}\text { 1. } 49455 \\
\text { 1. } 49319 \\
\text { 1. } 48950 \\
\text { 1. } 48874\end{array}$ & $\begin{array}{l}.86412 \\
.86100 \\
.86198 \\
.86175\end{array}$ & $\begin{array}{l}.85985 \\
.85666 \\
.85776 \\
.85748\end{array}$ & $\begin{array}{l}-47.976 \\
+13.233 \\
-99.581 \\
-96.043\end{array}$ & $\begin{array}{l}.0029 \\
.0008 \\
.0028 \\
.0004\end{array}$ \\
\hline
\end{tabular}

For air-saturated hydrocarbon in the liquid state at 1 atmosphere.

b See text for uncertainties of experimental values. 


\section{DENSITIES}

The measurements of density were made with a density balance, the assembly, calibration, and operation of which has been described [3]. The uncertainties of the values of density, which are reported in table 2, are estimated to be as follows: Precision, \pm 0.00002 to \pm 0.00003 ; accuracy (including the effect of impurities), \pm 0.00005 to \pm 0.00010 .

\section{BOILING POINTS}

The normal boiling points of these compounds were determined as part of another investigation on their vapor pressures, and the values reported in table 2 for the normal boiling point and the pressure coefficient of the boiling point at 1 atmosphere are taken directly from the report of that investigation [4]. The uncertainties in the values of the normal boiling point reported in table 2 are estimated to be as follows: Precision, \pm 0.002 to $\pm 0.003^{\circ} \mathrm{C}$; accuracy (including the effect of impurities), \pm 0.005 to $\pm 0.010^{\circ} \mathrm{C}$.

\section{FREEZING POINTS AND PURITIES}

The freezing point of the actual sample of each of the compounds (except for four of the octanes) was determined from time-temperature freezing and melting curves, by using the apparatus and procedure described in another report [5]. The values of freezing points are given in table 2 .

The purity of the actual sample was calculated, according to the method described in section VIII of reference [5], from the freezing point for zero impurity and values of the cryoscopic constants subsequently determined in another investigation on the preparation of API-NBS hydrocarbons [2,6]. The calculated amount of impurity is given in table 2. From the manner of preparation and purification of these compounds, it is believed that the impurities in each case are substantially all close-boiling isomers.

Grateful acknowledgment is made to the following persons and laboratories for supplying the materials for purification listed in table 1: C. E. Boord, supervisor of the API Research Project 45 (formerly the API Hydrocarbon Research Project) at the Ohio State University, Columbus, Ohio; M. R. Fenske, supervisor of the Petroleum Refining laboratory, Pennsylvania State College, State College, Pa.; George Calingaert, director of Chemical Research, Ethyl Corporation, Detroit, Mich.; Barrett Division of the Allied Chemical \& Dye Corporation, New York, N. Y.; Dow Chemical Co., Midland, Mich.; Humble Oil \& Refining Co., Houston, Tex. Additional thanks are due Professor Fenske for having supplied the very pure sample of cyclopentane. 


\section{REFERENCES}

[1] C. B. Willingham and F. D. Rossini, API Research Project 6; National Bureau of Standards. Unpublished.

[2] A. J. Streiff, E. T. Murphy, C. B. Willingham, V. A. Sedlak, and F. D. Rossini, API Research Project 6, National Bureau of Standards. Unpublished.

[3] A. F. Forziati, B. J. Mair, and F. D. Rossini, J. Research NBS 35, 513 (1945) RP1685.

[4] C. B. Willingham, W. J. Taylor, J. M. Pignocco, and F. D. Rossini, J. Research NBS 35, 219 (1945) RP1670.

[5] A. R. Glasgow, Jr., A. J. Streiff, and F. D. Rossini, J. Research National Bureau of Standards 35, 355 (1945) RP1676.

[6] A. R. Glasgow, E. T. Murphy, C. B. Willingham, and F. D. Rossini, API Research Project 6, National Bureau of Standards. Unpublished.

[7] J. H. Brunn, and W. B. M. Faulconer, Ind. Eng. Chem. Anal. Ed. 9, 192 (1937).

Washington, September 25, 1945. 